\title{
Upaya Guru Pendidikan Agama Islam dalam Mengembangkan Keaktifan Belajar Peserta Didik pada Pembalajaran Jarak Jauh
}

\author{
M. Dahlan R* \& Rizcka Fatya Rahayu \\ Universitas Ibn Khaldun Bogor, Indonesia \\ Jl. Sholeh Iskandar, RT.01/RW.10, Kedungbadak, Kec. Tanah Sereal, Kota Bogor. \\ *Email: dahlan@uika-bogor.ac.id
}

\begin{abstract}
The problem in this research is the decrease in the learning activeness of students during distance learning so that students experience learning boredom. Therefore, Islamic religious education teachers must strive to re-develop learning activeness and learning interest of students. The purpose of this study will be to conduct, study, study and research the efforts of Islamic religious education teachers in developing student learning activeness in distance learning in two schools in Cibungbulang sub-district, Bogor Regency; MTs Darul Ihsan and MTs Mathlahul Anwar in Indonesia. The method in this research uses a case study research approach, which is a method for collecting and analyzing data on a particular case. The results of this study are the various efforts of Islamic religious education teachers in developing student learning activeness in distance learning including: creating Whatsapp groups, motivating students, holding face to face learning every week, holding meetings with parents student guardians, and holding home visits.
\end{abstract}

Keywords: the efforts of Islamic religious education teachers; activity in study; Distance Education Teaching

Abstrak: Dampak dari adanya pembelajaran jarak jauh peserta didik mengalami kejenuhan belajar, sehingga menurunnya keaktifan belajar peserta didik saat proses pembelajaran. Oleh karena itu guru pendidikan agama Islam harus berupaya untuk mengembangkan kembali keaktifan belajar dan minat belajar peserta didik. Tujuan dari penelitian ini yaitu untuk mengembangkan keaktifan belajar peserta didik pada pembalajaran jarak jauh. Metode dalam penelitian ini menggunakan pendekatan penelitian studi kasus, yaitu merupakan metode untuk mengumpulkan dan menganalisis data suatu kasus tertentu. Hasil dari penelitian ini yaitu berbagai upaya guru pendidikan agama Islam dalam mengembangkan keaktifan belajar peserta didik pada pembalajaran jarak jauh meliputi: membuat group whatsapp, memotivasi siswa, mengadakan pembelajaran tatap muka setiap pekan, mengadakan pertemuan dengan orang tua wali murid, dan melakukan home visit. Temuan penelitian ini berimplikasi pada teori upaya guru dalam mengaktifkan belajar anak di masa pandemi dan di harapkan para guru pendidikan agama Islam bisa lebih meningkatkan strategi mengajarnya.

Kata Kunci: Upaya Guru PAI; Keaktifan Belajar; Pembelajaran Jarak Jauh

Jurnal Pendidikan Agama Islam Al-Thariqah Vol. 6, No. 1, Januari - Juni 2021

Received : 05 April 2021; Accepted : 15 April 2021; Published : 27 Juni 2021

*Corresponding Author : dahlan@uika-bogor.ac.id 


\section{PENDAHULUAN}

Dampak terjadinya pandemi Covid19 ini merubah sistem pembelajaran yang biasanya tatap muka sekarang berubah menjadi pembelajaran jarak jauh (Sadikin and Hamidah, 2020). Maka dari itu guru sangatlah berpengaruh dalam pembelajaran jarak jauh ini, bagaimana usaha seorang guru agar para peserta didik dapat terus aktif dan tetap ikut serta dalam pelaksanaan pembelajaran jarak jauh.

Proses pembelajaraan tidak bisa dilakukan hanya sendiri, melainkan harus melibatkan beberapa komponen yang berkaitan dengan pembelajaran agar terciptanya tujuan yang diharapkan (Ahmad and Tambak, 2017; Dahlan, 2016). Proses pembelajaran pada dasarnya menjadi sebuah proses aktifitas antara guru dengan peserta didik yang didalamnya terdapat interaksi, komunikasi dan pengalaman belajar yang dilakukan oleh guru dan peserta didik, sehingga keaktifan belajar peserta didik sangat berperan penting bagi keberhasilan proses pembelajaran.

Bisa dirasakan saat ini dalam proses pembelajaran jarak jauh komunikasi antara pendidik dengan peserta hanya melalui alat bantu media di dunia virtual yaitu melalui internet, dan jarang sekali untuk bertatap muka langsung saat proses pembelajaran. Dalam situasi saat ini salah satu ikhtiar yang jalani di dunia pendidikan agar pembelajaran tetap berjalan, walaupun para guru dan peserta didik merasakan proses pembelajaran jarak jauh ini kurang efektif dan tidak kondusif, sehingga para peserta didik pun merasakan kejenuhan belajar dan kurang aktif dalam melaksanakan pembelajaran jarak jauh ini. Oleh karena itu keaktifan dalam pembelajaran pun menurun, dan proses transfer ilmu dari guru pun terhambat (Zahara and Sina, 2020). Kegiatan Belajar dari rumah yang telah ditetapkan oleh pemerintah bertujuan agar dapat mendukung proses pembelajaran agar mempermudah para guru untuk bisa tetap menyampaikan meteri dengan baik kepada peserta didik.

Sejauh ini terdapat beberapa penelitian yang meneliti keaktifan belajar peserta didik di dunia pendidikan Islam. Penelitan Kudryashova, et al. (2015) di Rusia yang meneliti peran guru untuk memfasilitasi pembelajaran aktif yang berhasil dimana penelitian ini menentukan peran seorang guru yang mengajar secara optimal dalam setiap proses pembelajaran. Penelitian Niemi, et. al (2016) di Finlandia dan Turki yang meneliti tentang Pembelajaran aktif yang mempromosikan kompetensi profesional guru siswa. Penelitian Jeong, et. al (2019) di Spanyol, yang meneliti tentang pengaruh metodologi pembelajaran aktif terhadap emosi, keyakinan, dan pembelajaran efisiensi siswa hasil dalam kursus pembelajaran jarak jauh.

Penelitian Naziaha, et al. (2020) di Sukabumi, Indonesia dalam penelitiannya yaitu menganalisis keaktifan belajar peserta didik selama pembelajaran jarak jauh pada masa pandemi di sekolah dasar, dalam penelitiannya mengungkapkan bahwa selama pembelajaran jarak jauh berlangsung mengenai keaktifan belajarnya tidak sepenuhnya dapat dicapai dengan baik karena peserta didik mengalami kendala yang mengakibatkan keaktifan belajar peserta didik tidak dapat tercapai dengan baik.

Penelitian Purnami (2020) di Kalimantan Selatan, Indonesia dalam penelitiannya yaitu upaya meningkatkan keaktifan peserta didik dimasa pandemi melalui bimbingan klasikal secara onine sehingga dalam penelitiannya mengungkapkan bahwa siswa dapat mengikuti bimbingan klasikal, dan peserta didik aktif dalam melaksanakan tanya jawab melalui kolom komentar di classroom atau whatsapp group. Penelitian Al Halik and Aini (2020) di Banda Aceh, Indonesia dalam penelitiannya yaitu menganalisis keakitfan peserta didik dalam proses pembelajaran jarak jauh atau daring di 
masa pendemi, sehingga dalam penelitiannya pengungkapkan bahwa upaya dalam pembelajaran jarak jauh yang dilaksanakan oleh semua elemen pendidikan yang bertujuan agar peserta didik agar tetap belajar, karena peserta didik adalah sebagai subjek yang harus berperan aktif saat proses pembelajaran berlangsung, karena keakitfan peserta didik akan mempengaruhi keberhasilan proses pembelajaran. Penelitian Zaman (2020) di Aceh, Indonesia yang meneliti penerapan keaktifan belajar dalam pembelajaran pendidikan agama Islam, dalam penelitiannya yaitu penerapan metode active learning yang bertujuan untuk mengajak para peserta didik agar mampu berpikir kritis, lebih kreatif. Penelitian Sabaniah, et al. (2021) di Bandung, Indonesia yang meneliti peran guru selama proses pembelajaran jarak jauh di masa pandemi covid-19, dalam penelitiannya yaitu mengkaji dan melihat bagaiamana proses pembelajaran jarak jauh berlangsung.

Dari berbagai penelitian di atas mengarah pada menganalisis keaktifan belajar peserta didiknya dengan berbagai cara untuk bisa mengaktifkan peserta didik dalam proses pembelajarannya. Namun semua ini bukan hal yang mudah bagi semua komponen pendidikan, terutama para guru pada masa pandemi seperti sekarang ini yang berusaha semaksimal mungkin berupaya menghadapi transisi dalam sistem pembelajaran, yang semula dilaksanakan pembelajaran tatap muka, dan sekarang menjadi pembelajaran jarak jauh.

Maka, penelitian yang dilakukan ini mengacu kepada bagaimana seorang guru PAI berikhtiar dalam mengembangkan keaktifan belajar peserta didik dalam melaksanakan proses pembelajaran jarak jauh. Seorang guru adalah ujung tombak keberhasilan proses pembelajaran, dan dalam proses pembelajaran jarak jauh ini banyak sekali tantangan yang harus dihadapi, seperti halnya di sekolahsekolah atau daerah-daerah yang tertinggal.
Oleh karena itu pembelajaran jarak jauh tidak bisa laksanakan secara efektif dan efisien karena banyaknya tantangan yang dialami oleh masing-masing daerah, salah satunya yaitu di daerah Kecamatan Cibungbulang Kabupaten Bogor. Di sana masih banyak sekolah-sekolah yang mengalami berbagai kesulitan saat melaksnaakan pembelajaran jarak jauh. Salah satunya di dua Madrasah Tsanawiyah di kecamatan Cibungbulang Kabupaten Bogor yang akan peneliti lakukan, yaitu: MTs Darul Ihsan dan MTs Mathlahul Anwar. Peneliti memilih kedua sekolah tersebut karena para peserta didik di sana masih mengalami kendala saat melaksanakan proses pembelajaran jarak jauh, salah satunya yaitu keterbatasan peserta didik menguasai media pembelajaran jarak jauh dan kurangnya peran orang tua dalam mendampingi belajar anak-anaknya saat proses pembelajaran jarak jauh berlangsung, sehingga minat belajar anak pun semakin lama semakin menurun dan keaktifan belajar peserta didik pun ikut menurun.

Fakta yang terjadi di lapangan terdapat kesulitan yang dirasakan oleh guru PAI di MTs Darul Ihsan dan MTs Mathlaul Anwar dalam mengaktifkan peserta didik selama proses pembelajaran jarak jauh. Para guru PAI pun mengalami kesulitan dalam memilih strategi pembelajaran jarak jauh, dan pembelajaran pun terkesan monoton, sehingga keaktifan peserta didik pun berkurang dalam melaksanakan proses pembelajaran jarak jauh. Sedangkan dari peserta didiknya terdapat keterbatasan dalam memiliki dan menguasai media pembelajaran jarak jauh yang lebih canggih, sehingga para peserta didik menjadi tidak disiplin, dan mengalami kejenuhan selama proses pembelajaran.

Oleh karena itu para guru PAI di MTs Darul Ihsan dan MTs Mathlaul Anwar harus lebih bisa menyiapkan perangkat yang dapat menunjang proses pembelajaran dan mengubah strategi pembelajaran menjadi pembelajaran jarak 
jauh. Sehingga guru harus berfikir keras strategi apa yang dapat memungkinkan peserta didik belajar di rumah. Pengembangan belajar peserta didik di rumah menjadi sangat krusial sebagai asas utama bagi perkembangan anak (Kurniasari et al, 2020; Ahmad, Tambak and Syafitri, 2016).

Berdasarkan hal ini, bahwasannya seorang guru pedidikan agama Islam harus bisa berupaya untuk mendorong para peserta didik agar tetap aktif dan ikut serta dalam proses pembelajaran jarak jauh. Seorang guru maupun peserta didik harus bisa menghadapi transisi sistem pembelajaran yang awalnya dilaksanakan melalui pembelajaran tatap muka dan sekarang berubah menjadi pembelajaran jarak jauh. Fokus dalam penelitian ini yaitu upaya guru pendidikan agama Islam dalam mengembangan keaktifan belajar peserta didik pada pembelajaran jarak jauh, karena selama pembelajaran jarak jauh ini guru sebagai ujung tombak keberhasilan pendidikan, khususnya saat adanya transisi sistem pembelajaran yang berubah menjadi pembelajaran jarak jauh, sehingga dibutuhkannya keaktifan belajar peserta didik dalam proses pembelajaran. Dengan demikian, tujuan dari penelitian ini penulis akan mengembangkan keaktifan belajar peserta didik pada pembelajaran jarak jauh.

\section{KONSEP TEORI}

\section{Upaya guru pendidikan agama Islam}

Makna upaya dalam kamus besar bahasa Indonesia, upaya berarti usaha atau ikhtiar, yaitu usaha dalam mencapai tujuan tertentu atau menyelesaikan suatu masalah tertentu (Darajat et al, 2019). Maka dari itu upaya dalam penelitian ini adalah sebagai suatu upaya guru pendidikan agama Islam. Maka, upaya merupakan usaha atau ikhtiar seorang guru pendidikan agama Islam untuk melakukan sesuatu hal yang memiliki tujuan tertentu untuk memecahkan suatu masalah dengan melakukan berbagai solusi yang direncanakan yaitu ingin menganlisis dan mencari solusi bagaimana mengembangkan keaktifan belajar siswa pada pembelajaran jarak jauh.

Menurut Zein (2016) pembelajaran adalah upaya guru dalam membelajarkan peserta didik, dengan cara melakukan kegiatan yaitu memilih, merencanakan, dan mengembangkan strategi pembelajaran agar mencapai hasil pembelajaran yang diharapkan sesuai dengan situasi pembelajaran yang dihadapi. Adapun prinsip yang perlu dimiliki guru PAI dalam upaya kegiatan proses pembelajaran meliputi memunculkan minat belajar siswa, memberikan motivasi, dan guru harus bisa membuat strategi pembelajaran yang dapat mencapai keberhasilan pembelajaran dalam situasi apapun (Hamzah, Tambak and Ariyani, 2017).

Upaya guru pendidikan agama Islam saat proses pembelajaran salah satunya yaitu harus pintar memilih media dan metode pembelajaran, karena dua hal tersebut dapat menentukan keberkasilan proses pembelajaran yang dilaksanakan oleh guru terhadap siswa. Dan Penggunaan media dan metode pembelajaran sangat mempengaruhi interaksi peserta didik dan guru dalam proses pembelajaran (Lestari, 2016). Menurut Hambali (2016) kemampuan (kompetensi) yang harus dimiliki guru pendidikan agama Islam (GPAI) meliputi: kompetensi personal (kepribadian), kompetensi professional, kompetensi sosial, kompetensi pedagigik, dan kompetensi kepemimpin. Salah satu kompetensi guru PAI yang harus dimiliki yaitu kompetensi pedagogik merupakan kemampuan guru saat mengelola pembelajaran, dan juga kemampuan guru dalam memahami kurikulum, memanfaatan media pembelajaran atau teknologi pembelajaran dan dapat mengevaluasi hasil pembelajaran peserta didik. (Siswanto and Susanti, 2018; Tambak, et al. 2018). 
Maka dari itu guru Pendidikan Agama Islam harus mampu menguasai teknologi pembelajaran dan strategi pembelajaran agar proses pembelajaran dapat berjalan dengan baik kepada peserta didik. Haibah et. al (2020) mengatakan pendidikan dalam Islam itu bukan hanya perihal pemberian ilmu saja namun juga pemberian ketakwaan, keimanan, dan pembiasaan akhlak yang baik terhadap peserta didik. Sehingga Adanya pendidikan juga diharapkan bisa mencerdaskan anak bangsa untuk menciptakan kehidupan yang lebih baik. Agar tercapainya proses pendidikan, maka seorang guru harus bisa semaksimal mungkin dalam menciptakan strategi mengajar dengan baik (Siregar, 2020; Tambak, et al. 2020)

Dalam Islam terdapat prinsipprinsip yang harus diupayakan oleh seorang pendidk yang profesional yaitu: 1) Di dalam Islam seorang pendidik harus mengajar sesuai dengan keahlian yang dimilikinya; 2) Di dalam Islam seorang musim ketika ia melakukan sesuatu harus ikhlas karna Allah, seperti halnya untuk seorang guru yang harus bertaanggung jawab atas tugas-tugas yang diembannya dan harus ikhlas lillahi ta'ala, dan Allah pun pasti akan membalas segala kebaikan yang telah dilakukan seorang guru. (Ramayulis, 2016; Tambak, Amril, and Sukenti, 2021).

Tugas seorang guru yaitu menjadi seorang model atau aktor bagi peserta didiknya, agar bisa memotivasi peserta didik agar aktif dalam mengikuti pembelajaran, dan guru juga harus bisa menyampaikan nasehat-nasehat positif kepada peserta didiknya (Wahyuni and Putra, 2020). Dalam menciptakan kondisi pembelajaran guru pendidikan agama Islam harus berupaya, terdapat beberapa indikator seorang guru dalam menciptakan kondisi pembelajaran: 1) memiliki sikap yang peka, 2) memberikan arahan yang jelas dalam memberikan materi, 3) memberikan reward dan punishment, 4) dapat mengatur kondisi pembelajaran (Tambak, Amril, and Sukenti, 2021).

\section{Keaktifan Belajar Peserta didik}

Keberhasilan dalam proses pembelajaran akan dikatakan sukses dan berhasil apabila guru dan peseta didik mampu berkerja sama dalam menjalankan proses pembelajaran dan mengendalikan proses pembelajaran dengan semestinya, dan seorang guru merupakan ujung tombak dalam keberhasilan proses pembelajaran (Mansir and Purnomo, 2020; Tambak, Ahmad and Sukenti, 2020). Setiap proses pembelajaran peserta didik harus dituntut untuk selalu memperlihatkan keaktifan belajar mereka. Dalam suatu keaktifan terdapat suatu kegiatan di dalamnya, meliputi: kegiatan fisik dan kegiatan psikis. Kegiatan fisik bisa berupa membaca, mendengar, menulis, berlatih keterampilanketerampilan, dan lain sebagainya. Adapun kegiatan psikis misalnya memperkaya pengetahuan yang dimiliki dalam memecahkan suatu problematika yang dihadapi mereka atau pun suatu kajian ilmu pengetahuan (Rusman, 2017).

Menurut Suarni (2017) makna keaktifan belajar adalah cara agar peserta didik menjadi aktif melalui aktivitasaktivitas yang dapat membuat para peserta didik berpikir tentang materi yang diajarkan guru. Menurut Hotmian (2018) indikator yang dapat digunakan untuk mengukur keaktifan peserta didik sebagai berikut: 1) Pemecahan Masalah yaitu, menyelesaikan masalah dengan mencari solusi dengan cara membaca diberbagai literature atau buku, Bertanya pada guru ketika mengalami kesulitan dalam belajar, bertanya kepada kawan yang sudah materi pelajaran. 2) Kerjasama yaitu, menghargai perbedaan pendapat, bekerjasama dengan baik dalam mengerjakan tugas kelompok. 3) Perhatian yaitu, peserta didik perlu mencatat ilmu-ilmu atau materi yang disampaikan guru, peserta didik harus fokus dalam melaksanakan proses pembelajaran, memperhatikan dan 
mendengarkan apa yang disampaikan oleh guru.

Dalam aktifitas selama proses pembelajaran diperlukan keaktifan siswa, karena dalam proses pembelajaran akan berhasil jika seluruh peserta didik dapat mengikuti pembelajaran secara aktif, baik secara mental, sosial maupun secara fisik dalam proses pembelajaran. Oleh karena itu aspek-aspek keaktifan belajar peserta didik tersebut meliputi: (a) keberanian, (b) berpartisipasi, (c) kreativitas belajar dan (d) kemandirian belajar (Nugraha, 2019; Hamzah, et. al, 2020).

Melalui proses pembelajaran yang aktif peserta didik diharapkan sadar dan mengenal cara belajarnya, sehingga peserta didik dapat menyelesaikan masalah kesulitan belajarnya. Pembelajaran aktif menuntut guru untuk memiliki kompetensi profesioanal dan menjadikan proses pembelajaran yang dilakukan adalah pengalaman untuk peserta didik. Oleh karena itu untuk melaksanakan proses pembelajaran aktif guru harus memiliki kemampuan sebagai berikut: 1) Memanfaatkan sumber belajar yang ada, 2) Memiliki kreasi dalam mengajar, 3) Harus bisa mengaitkan materi dengan kehidupan 4) Memberikan pengetahuan secara bertahap, 5) Memberikan kesempatan untuk peserta didik berkembang dalam belajarnya sesuai dengan kemampuannya, 6) menerapkan prinsip-prinsip pembelajaran aktif saat proses pembelajaran berlangsung (Hartini, 2017).

\section{Pembelajaran Jarak Jauh}

Pembelajaran Jarak merupakan sebuah pelaksanaan pembelajaran dengan menggunakan bebapa teknologi yang dapat menunjang keberhasilan pembelajaran, karena proses pembelajaran jarak jauh ini antara pembelajar dan pengajar tidak ada tatap muka secara langsung dalam pemberian materi pelajaran (Prawiyogi, et al, 2020). Ada beberapa media pembelajaran yang berupa aplikasi yang dapat dijadikan pilihan dalam proses pembelajaran jarak jauh, yaitu berupa, whatsapp, zoom, googlemeet, google classroom dan lain sebagainya. Dari beberaapa media diatas diharapkan dapat mengembangkan keaktifan belajar peserta didik ketika melaksanakan pembelajaran jarak jauh (Dharma, 2021).

Terdapat berbagai macam ragam proses belajar dalam pembelajaran jarak jauh yaitu; a) belajar individu; b) belajar dibimbing; c) mengadakan pembelajaran tatap muka yaitu: proses pembelajaran jarak jauh dilakukan dengan mempersyaratkan adanya pembelajaran tatap muka secara langsung, namun ada persyaratan yang harus dilakukan yaitu tetap menjaga protokol kesehatan; d) melalui elektronik yaitu dengan cara pembelajaran online melalui aplikasi belajar (Abidin et al, 2020). Model pembelajaran jarak jauh menurut Setyaningsih (2020) bahwa model pembelajaran e-learning saat pembelajaran jarak jauh terdiri tiga cara yaitu; 1) guru mengirimkan materi pelajaran secara online kemudian peserta didik mendownload dan mempelajarinya secara manual (offline); 2) guru memberikan materi pembelajaran secara online dan peserta didik mempelajari secara online juga seperti menggunakan zoom meeting atau google meeting; dan 3) melakukan cara antara pembelajaran secara langsung dengan pembelajaran secara offline.

\section{METODE PENELITIAN}

Dalam penelitian ini, peneliti menggunakan penelitian studi kasus (case study), merupakan metode untuk mengumpulkan dan menganalisis data suatu kasus tertentu. Studi kasus dipusatkan pada mengkaji kondisi, atau suatu kegiatan (Hardani, 2020). Penelitian studi kasus ini memfokuskan diri secara mendalam terhadap beberapa permasalahan yang menjadi sasaran yaitu dengan cara mempelajari kasus tersebut (Muhyani, 2020). Oleh karena itu 
penelitian ini bertujuan untuk mengkaji, menelaah, dan menganalisis upaya guru pendidikan agama Islam dalam mengembangkan keaktifan belajar peserta didik pada pembalajaran jarak jauh. Penelitian ini dilakukan di dua sekolah di kecamatan Cibungbulang Kabupaten Bogor; MTs Darul Ihsan dan MTs Mathlahul Anwar di Indonesia.

Adapun informan dalam penelitian ini yaitu empat guru pendidikan agama Islam di MTs Darul Ihsan dan MTS Mathlaul Anwar. Informan tersebut mengajar pada mata pelajaran Fiqih dan Aqidah Akhlak. Keempat informan dalam penelitian ini berjenis kelamin perempuan, satu informan lulusan magister program studi pendidikan agama Islam dan tiga infroman lainnya lulusan sarjana program studi pendidikan agama Islam. Keempat informan merupakan lulusan pondok pesantren, dengan lama mengajar 5-20 tahun, dan usia 25-50 tahun.

Teknik pengumpulan data dalam penelitian ini menggunakan teknik wawancara secara mendalam dengan informan, yaitu dua guru di MTs Darul Ihsan dan dua guru di Mts Mathlaul Anwar. Setiap guru berpartisipasi dalam proses wawancara yang telah peneliti siapkan, dan peneliti menyiapkan pedoman wawancara sebagai rujukan dalam pengumpulan data ini. Wawancara ini dilakukan tiga kali dengan informan dalam mengumpulkan data. Wawancara pertama yaitu peneliti menanyakan kepada guru bagaimana sistem pembelajaran jarak jauh di sekolah tersebut, wawancara ke dua peneliti menanyakan kepada guru tentang keaktifan belajar peserta didik, dan wawancara yang ke tiga peneliti menggali bagaimana upaya yang dilakukan guru pendidikan agama Islam dalam mengembangkan keaktifan belajar peserta didik pada pembelajaran jarak jauh.

Analisis data dalam penelitian ini menggunakan beberapa langkah-langkah, menurut Muhyani (2020) yaitu; pertama mengumpulan data melalui wawancara; kedua, reduksi data yang didapatkan atau memilah data dan selanjutnya yaitu pengkodingan, peneliti melakukan pengkodingan data yang bertujuan untuk mengelompokan data sesuai dengan tema yaitu upaya guru PAI yang telah peneliti dapatkan dari informan, sehingga peneliti mendapatkan beberapa upaya guru pendidikan agama Islam yang sering muncul dari ke empat informan ini dalam mengembangkan keaktifan belajar peserta didik pada pembelajaran jarak jauh; ketiga, data yang terkumpul kemudian dianalisa untuk membuat interpretasi dan genaralisasi; keempat, penyajian data dengan memberikan kesimpulan dan implikasi dari hasil penelitian. Dengan langkah-langkah tersebut peneliti menghasilkan data yang akan peneliti kaji dan analisis yaitu berisi upaya-upaya yang dilakukan guru pendidikan agama Islam dalam mengembangkan keaktifan belajar peserta didik pada pembalajaran jarak jauh.

\section{HASIL DAN PEMBAHASAN}

Dari hasil penelitian yang telah lakukan terdapat berbagai upaya guru pendidikan agama Islam dalam mengembangkan keaktifan belajar peserta didik pada pembalajaran jarak jauh. Upaya adalah suatu bentuk ikhtiar atau usaha seorang dalam melakukan berbagai hal atau suatu pekerjaan, seperti halnya seorang guru PAI di MTs Darul Ihsan dan MTs Mathlaul Anwar yang berupaya untuk melaksanakan tanggung jawabnya sebagai pengajar sekaligus pendidik bagi peserta didiknya.

Bagi guru PAI di MTs Darul Ihsan dan MTs Mathlaul Anwar, pembelajaran jarak jauh seperti sekarang ini menjadi tantangan besar untuk bisa menciptakan pembelajaran yang aktif, kreatif, menyenangkan dan inovtif. seorang guru yang harus bertaanggung jawab atas tugas-tugas yang diembannya dan harus ikhlas lillahi ta'ala. Oleh karena itu seorang guru harus bisa berusaha dan berikhtiar menjalankan segala tugas-tugas dan tanggung jawabnya dengan ikhlas 
mengharap ridha Allah. Guru pun harus berusaha untuk meningkatkan keaktifan belajar peserta didik dengan cara mencari strategi-strategi untuk bisa membangkitkan semangat peserta didik dalam proses kegiatan belajarnya. Sebab keaktifan belajar itu sangat penting bagi peserta didik agar peserta didik paham terkait ilmu yang diberikan guru.

Adapun hasil penelitian yang telah peneliti lakukan melalui wawancara secara mendalam dengan informan yaitu guru pendidikan agama Islam, maka peneliti menemukan beberapa upaya guru pendidikan agama Islam dalam mengembangkan keaktifan belajar peserta didik pada pembalajaran jarak jauh sebagai berikut:

\section{Membuat Grup Whatsapp}

Di masa pendemi seperti saat ini guru dituntut untuk bisa menguasai berbagai tekonologi, khususnya teknologi yang bisa menunjang keberhasilan pembelajaran. Hal ini mengefektifkan pembelajaran menggunakan teknologi saat ini dimana mengharuskan guru dan peserta didik aktif saat proses pembelajaran berlangsung. Hal ini juga diterapkan oleh guru Pendidikan Agama Islam di MTs Darul Ihsan dan MTs Mathlaul Anwar.

Dalam penelitian ini yang terjadi di lapangan, yaitu terdapat keterbatasan penggunaan media pembelajaran yang lebih canggih yang tidak bisa digunakan oleh peserta didik di MTs Darul Ihsan dan MTs Mathlaul Anwar, sehingga pihak sekolah memutuskan kepada para guru PAI untuk menggunakan aplikasi whatsapp menjadi media pembelajaran jarak jauh karena aplikasi whatsapp adalah aplikasi yang lumrah dimasyarakat dan tidak memakan kuota yang banyak dalam pemakaiannya. Whatsapp group dapat dibuat berdasarkan kelas, ataupun berdasarkan mata pelajaran yang ada di sekolah, sehingga siswa dan guru dapat berkomunikasi melalui whatsapp group.
Hal ini sebagaimana yang dikemukakan oleh guru PAI sebagai berikut: "Media mengajar yang digunakan di sekolah ini saat pelaksanaan pembelajaraan jarak jauh yaitu hanya memakai whatsapp group untuk menunjang keberhasilan pembelajaran, karena whatsapp adalah salah satu aplikasi yang sering dipakai semua orang dan pemakaiannya pun mudah, apalagi saat pembelajaran jarak jauh seperti sekarang ini, semua serba online."

Whatsapp adalah aplikasi yang hampir banyak yang memilikinya, sehingga tidak ada kesulitan bagi seorang guru untuk mengedukasi atau memberitahukannya dan mereka pun pasti sudah tau bagaimana cara mengoprasikan aplikasi whatsapp ini. Di dalam aplikasi whatsapp terdapat fitur yang bisa dimanfaatkan sebagai media pembelajaran seperti saat ini, dengan menggunakan whatsapp group ini guru bisa membantu para peserta didik menyediakan tempat belajar online.

Dengan menggunakan whatsapp group, guru dan peserta didik di MTs Darul Ihsan dan MTs Mathlaul Anwar bisa melaksanakan pembelajaran jarak jauh dengan mudah karena aplikasi whatsapp banyak bisa yang menggunakannya. Beda hal nya di sekolah yang elit dan masyarakatnya menengah ke atas mereka menggunakan media pembelajaran berupa google meet, classroom, ataupun zoom meeting untuk melaksanakan pembelajaran jarak jauh (Rosenberg, Hananel, and Asterhan, 2018).

Temuan penelitian ini diperkuat dengan penelitian yang dilakukan oleh Pratama et. al (2016) menyatakan bahwa implementasi whatsapp sebagai mobile learning dapat meningkatkan hasil belajar karena penggunaan aplikasi whatsapp messenger sangat membantu peserta didik dan guru agar lebih aktif dalam berkomunikasi dan berinteraksi melalui grup yang sudah dibuat. Pembelajaran dapat lebih aktif sehingga pesan 
pendidikan dapat diterima oleh peserta didik dengan baik.

Hasil penelitian ini juga sesuai dengan penelitian yang dilakukan oleh Manurung (2020) menyatakan bahwa aplikasi whatsapp adalah sebagai teknologi atau media sosial yang dapat berpengaruh di kalangan masyarakat, sehingga banyak yang menggunakannya, peserta didik dan guru dapat berdiskusi melalui whatsapp, peserta didik dan guru juga dapat menshare pelajaran atau mengumpulkan tugas-tugasnya karena di dalam aplikasi whatsapp terdapat fiturfitur yaitu: whatsapp story, berbagi foto, video, atau link website.

Namun berbeda dengan hasil penelitian yang dilakukan oleh Kusuma et. al (2020) yang menyatakan bahwa pembelajaran jika dilakukan hanya dengan whatsapp group tidak akan efektif, jadi harus dibantu dengan media lain atau aplikasi lain agar pembelajaran tidak terkesan monoton, namun ada juga beberapa peserta didik yang mengeluhkan dengan penggunaan aplikasi lain karna sedikit ribet dan memakan kuota yang banyak dan peserta didik lebihi nyaman belajar dengan whatsapp group.

Melalui group whatsapp ini guru PAI di MTs Darul Ihsan dan MTs Mathlaul Anwar dapat berikhtiar untuk mengaktifkan pembelajaran agar materi pelajaran yang diberikan kepada peserta didik dapat dimengerti dan tujuan pembelajaran pun akan tercapai sesuai rencana. Sebagaimana yang diungkapkan oleh guru PAI bahwa: "Penggunaan whatsapp group bisa mengaktifan siswa dalam pelaksanaan pembelajaran, walaupun sekarang melalui online yaitu dengan menggunakan whatsapp group, guru bisa melihat peserta didik mana yang aktif dalam proses pembelajaran, misalnya peserta didik yang menjawab dan memberi pertanyaan di group, merespon guru di group, dan mengerjakan tugas tepat waktu, karena saat pembelajaran jarak jauh ini guru PAI di MTs Darul Ihsan dan MTs Mathlaul Anwar hanya bisa melihat perkembangan belajar mereka dari keaktifan belajar di group whatsapp".

Melalui whatsapp group menurut salah seorang guru Pai di MTs Darul Ihsan, "hanya bisa melihat keaktifan belajar peserta didiknya dengan cara menggunakan metode tanya jawab antara guru dan peserta didik. Melalui whatsapp group juga guru dapat memperhatikan siapa saja yang benar-benar menyimak materi pelajaran ketika guru mengajukan pertanyan kepada mereka dan merekapun merespon di group whatsapp. Dengan demikian ketika peserta didik mengerjakan tugas, guru dapat mengetahui siapa saja peserta didik yang mengerjakan tugas tepat waktu. Di bawah ini adalah salah satu group whatsapp yang miliki oleh guru PAI".

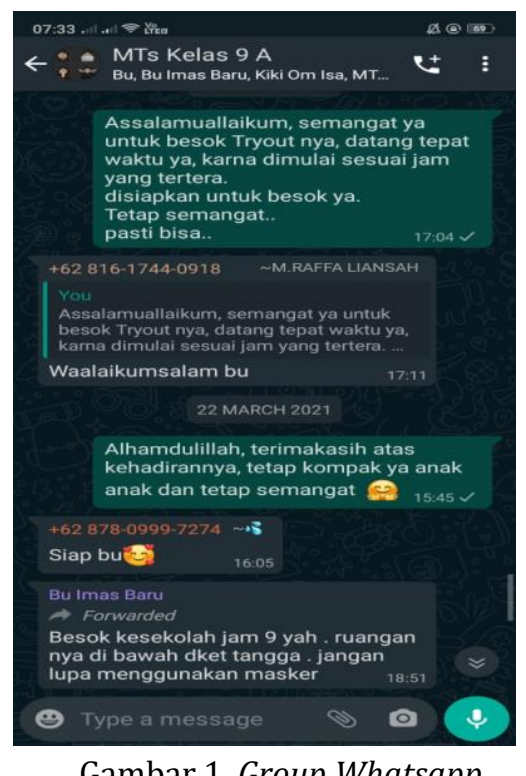

Dengan adanya grup whatsapp ini dapat mengaktifkan peserta didik saat pelaksanaan pembelajaran jarak jauh seperti sekarang ini, karena peserta didik bisa berkomunikasi dengan guru, dan bisa menanyakan materi-materi yang peserta didik kurang pahami. Melalui group whatsapp juga guru dengan mudah memberikan informasi, tugas dan materimateri berupa video, gambar, audio, dokumen-dokumen maupun link-link agar peserta didik bisa lebih mudah mengaksesnya (Zulkanain, et al. 2020). 


\section{Memotivasi Peserta Didik}

Memotivasi peserta didik merupakan faktor penting dilakukan oleh guru pendidikan agama Islam pada peserta didik. Sebab, faktor yang mempengaruhi keaktifan belajar peserta didik salah satunya yaitu faktor internal peserta didik, merupakan faktor yang berasal dari dalam diri peserta didik itu sendiri, yang meliputi tingkat kecerdasan peserta didik, kemandirian belajarnya, minat, bakat, dan motivasi yang ada dalam dirinya (Tambak and Sukenti, 2020; (Amry and Badriah, 2018). Di sisi lain, faktor eksternal yang dapat mempengaruhi belajar peserta didik salah satunya yaitu faktor lingkungan sosial. Faktor lingkungan sosial dapat memengaruhi belajar peserta didik meliputi lingkungan sekitar sekolah seperti teman-temannya, para guru, dan para staff sekolah(Arianti, 2018; Sukenti and Tambak, 2020).

Oleh karena itu lingkungan sangat berpengaruh terhadap minat belajar peserta didik, sehingga dibutuhkannya motivasi oleh orang-orang terdekat seperti orang tua, ataupun guru kepada peserta didik agar lebih bersemangat dalam melaksanakan proses pembelajaran. Dari hasil temuan di lapangan bahwa pentingnya seorang pendidik dalam memotivasi belajar peserta didik ini bertujuan agar minat belajar peserta didik tidak menurun karena disebabkan sistem pembelajaran yang berbeda dari biasanya. Sebagaiman yang dijelaskan guru PAI di MTs Mathaul Anwar sebagai berikut:

"Memotivasi peserta didik adalah bentuk usaha seorang guru agar siswa tidak mengalami kejenuhan dalam menjalani pembelajaran jarak jauh seperti sekarang ini. Sebab di masa pandemi seperti sekarang peserta didik pasti mengalami kejenuhan saat belajar di rumah dan mereka juga tidak bertemu dengan teman-temannya. Bahkan jika di rumah anak sering dimarahi oleh orang tuanya karena berbagai hal, sehingga anak pun sering mengalami bosan dan jenuh ketika belajar di rumah."

Dari pemaparan di atas dapat diketahui bahwa memotivasi peserta didik sangat berpengaruh dalam pembelajaran jarak jauh. Sebab ketika proses pembelajaran jarak jauh, peserta didik dituntut untuk belajar secara mandiri di rumah, peserta didik pun lama kelamaan mengalami bosan dan jenuh dalam belajar. Oleh karena itu peserta didik membutuhkan motivasi agar tetap bersemangat dan aktif dalam melaksanakan proses pembelajaran jarak jauh ini dengan baik.

Hasil penelitian ini sesuai dengan penelitian oleh Fadriah et. al (2021) bahwa seorang guru ternyata mempunyai figur yang sangat penting dalam memotivasi peserta didik yang dimana proses pemebelajaran jarak jauh ini harus berjalan secara efektif dan efisien agar tujuan pembelajaran dapat tercapai dengan semestinya. Temuan penelitian ini juga dapat diperkuat oleh penelitian Haspira et. al (2021) yang menyatakan bahwa motivasi sangatlah penting yang harus ditingkatkan bagi peserta didik yang malas dalam melaksanakan proses pembelajaran di masa pandemi saat ini, karena yang bisa membantu dalam keberhasilan pendidikan ini bukan hanya guru saja namun peserta didiknya itu sendiri yang berusaha untuk meningkatkan pengetahuan dalam memahami materi pembelajaran yang disamapikan guru.

Oleh karena itu seorang guru PAI harus bisa mempengaruhi belajar peserta didiknya dengan cara memotivasi perserta didiknya agar dalam proses pembelajaran peserta didik itu terdapat rangsangan, minat belajar, atau kemandirian belajar sehingga kecerdasaanya pun akan meningkat (Ahmad, and Tambak, 2018; Sukenti and Tambak, 2019). Sebab, jika peserta didik kurang semangat dan jenuh saat belajar maka keaktifan belajar pun akan menurun 
dan proses transfer ilmu dari guru pun tidak diterima dengan baik (Graham, 2020).

Ryan, and Deci (2020) mengungkapkan bahwa memotivasi siswa adalah salah satu upaya seorang guru dalam mengaktifkan belajar peserta didik agar lebih semangat dalam belajarnya. Memotivasi peserta didik adalah upaya yang sangat efektif sekali, karena ketika guru memberikan semangat atau motivasi kepada peserta didiknya maka guru pun dengan mudah menyampaikan materinya. Motivasi yang diberikan guru berdampak pada hasl pembelajaran dan minat belajar peserta didik dalam pembelajaran.

\section{Mengadakan Pembelajaran Tatap Muka Setiap Pekan}

Proses pembelajaran jarak jauh seperti saat ini, guru dan peserta didik tentu sangat kewalahan jika tidak mengadakaan pertemuan tatap muka. Sebab dikhawatirkan semangat belajar peserta didik akan menurun dan mereka pun jenuh dalam belajarnya, kurang bergairah dalam mengikuti pembelajaran tatap muka di sekolah. Fakta yang terjadi di dua sekolah yang peneliti lakukan, walaupun sedang melaksanakan pembelajaran jarak jauh melalui pembelajaran online, pihak sekolah memutuskan untuk mengadakan pembelajaran tatap muka. Hal ini bertujuan agar peserta didik tidak jenuh belajar dan guru pun menyampaikan materi pelajaran sedikit manjadi lebih efektif dan efisien. Sebagaimana yang dijelaskan guru PAI terkait pelaksanaan tatap muka di masa pandemi sebagai berikut:

"Dalam pelaksanaan pembelajaran jarak jauh saat ini, jika peserta didik tidak ada sama sekali pertemuan tatap muka, maka dikhawatirkan adalah semangat belajar mereka akan menurun sehingga mereka tidak ada rasa ingin belajar atau tidak ada gairah untuk bersekolah. Ketika materi yang sudah tersampaikan melalui grup whatsapp peserta didik, jika ada yang belum dipahami bisa menanyakan materi yang belum dipahami saat pertemuan tatap muka dilakukan. Jika tidak ada sama sekali pertemuan tatap muka dilakukan, paling tidak satu kali dalam satu pekan, sebagai guru saya merasa kasihan kepada peserta didik, dan dikhawatirkan ada materi yang mereka belum paham dan belum mengerti sama sekali. “

Seorang guru PAI di MTs Mathlaul Anwar mengungkapkan, "dalam pertemuan tatap muka setiap pekan ini, bertujuan agar guru bisa menjelaskan kembali materi yang telah disampaikan melalui whatsapp group agar peserta didik lebih memahami materi pembelajaran dan mesti dilaksanakan secara langsung melalui tatap muka. Peserta didik pun mempunyai rasa tanggung jawab dalam belajarnya, karena saat pembelajaran jarak jauh berlangsung peserta didik ada rasa tidak takut, dan peserta didik pun sering tidak mengerjakan tugasnya." Di bawah ini adalah dokumentasi pelaksanaan pembelajaran tatap muka setiap pekan.

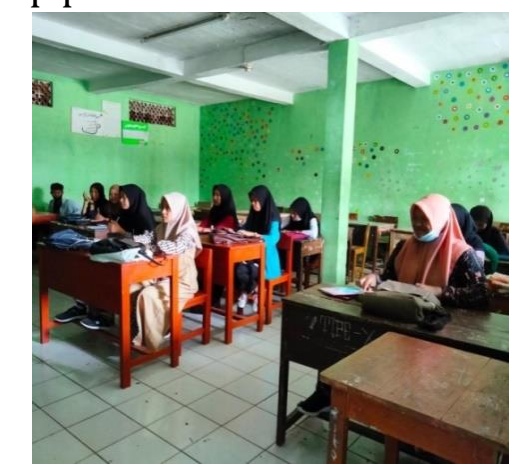

Gambar 2. Pertemuan tatap muka satu pekan sekali

Dalam pertamuan ini, seorang guru PAI di MTs Darul Ihsan mengutarakan bahwa, "guru menjelaskan ulang materi yang sudah disampaikan melalui grup whatsapp. Maka peserta didik di pertemuan ini dapat secara langsung bertanya materi yang belum mereka pahami. Peserta didik dapat bertanya secara langsung mengenai hal-hal yang belum jelas dan belum dipahami, ataupun bertanya jawab seputar meteri pembelajaran. Jika tidak ada pertemuan 
sama sekali, para guru sangat khawatir jika ada materi yang kurang tersampaikan dan belum dipahami oleh peserta didik.

Hasil penelitian ini diperkuat oleh penelitian Sabiq (2020) bahwa pembelajaran dengan tatap muka masih tak dapat ditinggalkan dan digantikan oleh media flat form online dalam kemajuan teknologi saat ini. Walaupun pembelajaran jarak jauh secara online dengan berbagai flat form yang digunakan, tetap saja tatap muka harus dilakukan dan dikombinasikan agar pemahaman peserta didik tidak menurun dan motivasi belajar mereka juga tidak menurun. Pembalajaran jarak jauh dan tatap muka idealnya dipadukan dalam proses pembelajaran di masa pandemi.

\section{Mengadakan Pertemuan dengan Orang Tua Wali Murid}

Dalam pembelajaran jarak jauh saat ini di masa pandemi, yang berperan penting dalam proses pembelajaran bukan hanya guru saja, namun para orang tua sangat berperan penting. Sebab dalam proses pembelajaran jarak jauh ini dilakukan oleh guru dari sekolah dan peserta didik berada di rumah. Dengan demikian proses pembelajaran jarak jauh menuntut kerjasama orang tua di rumah bersama dengan guru secara maksimal.

Oleh karena itu pihak sekolah memutuskan untuk mengadakan pertemuan dengan dengan orang tua wali murid untuk mengetahui bagaiman proses pembelajaran peserta didik selama di rumah. Sehingga tujuan diadakannya pertemuan dengan wali murid sebagaimana yang dijelaskan oleh guru PAI sebagai berikut:

"Tujuan diadakannya peretemuan dengan wali murid yaitu untuk mengetahui bagaimana orang tua mengontrol belajar anaknya saat pembelajaran jarak jauh berlangsung. Apakah mereka acuh, atau mereka memeprhatikannya anaknya. Sehingga kita harus bekerja sama antara pihak sekolah yaitu guru dengan orang tua peserta didik. Oleh karena itu orang tua pun harus mengetahui perkembangan anaknya, dan guru pun bisa mengetahui kendala yang dirasakan oleh para orang tua di rumah saat peserta didik belajar di rumah, apakah anak itu bermalasmalasan atau anak itu lebih sering bermian handphone. Sehingga sebagai guru pun mengetahui apa permasalahan yang dihadapi semua orang tua wali murid, dan kita mencari solusinya bersama."

Pertemuan orang tua dengan pihak sekolah sebagai salah satu upaya untuk memperkuat proses pembelajaran jarak jauh di masa pandemi. Sebab orang tua merupakan mitra guru dari sekolah untuk bersama-sama mengajar anak. Oleh karena itu, menurut seorang guru PAI mengungkapkan, "tujuan diadakannya pertemuan dengan wali murid saat proses pembelajaran jarak jauh seperti sekarang ini yaitu untuk mengetahui kendala yang dirasakan para orang tua di rumah saat peserta didik diharuskan belajar dirumah, sehingga pihak sekolah terutama guru bisa mencari solusi atas permasalahan yang dialami para orang tua di rumah."

Menurut seorang guru PAI, "pihak sekolah mengadakan pertemuan dengan orang tua wali murid harapkan memiliki kerja sama yang baik. Sehingga pihak sekolah dapat mengetahui apa saja kendala yang dialami oleh para orang tua di rumah saat anak-anaknya belajar. Oleh karena itu seorang guru dapat mengetahui apa saja permasalahan yang dihadapi semua orang tua wali murid, dan kita dari pihak sekolah dapat mencari solusinya bersama. Di bawah ini dokumentasi saat pertemuan wali murid.

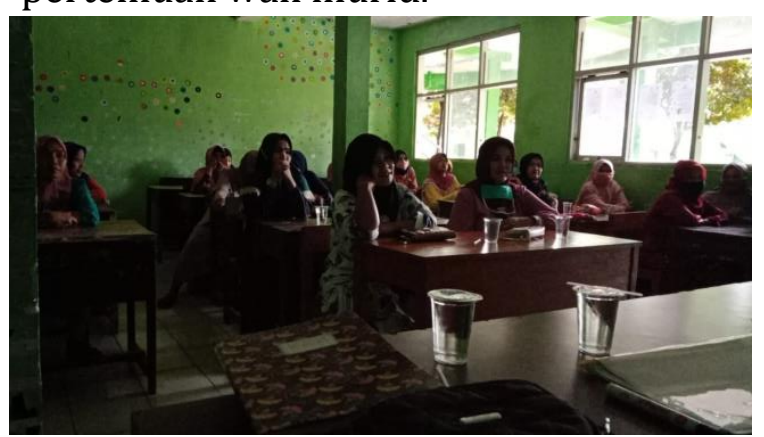


Gambar 3. Pertemuan dengan wali murid

Temuan penelitian ini diperkuat oleh penelitian yang dilakukan Yulianingsih et. al (2020) yang menyatakan bahwa keterlibatan orang tua dalam di masa pandemi saat ini mengharuskan para orang tua untuk terlibat banyak dalam pendampingi anak dalam belajar, karena orang tua memiliki peran sebagai pembelajar untuk anak, yang bisa memenuhi kebutuhahan anak melalui beberbagai aspek yang meliputi kognitif, afektif, psikomotorik anak selama dirumah, dan orang tua juga sebagai pengawas, motivator, penyedia fasilitas anaknya ketika belajar di rumah.

Hasil penelitian ini diperkuat dengan penelitian yang dilakukan oleh Kusumah and Cahyati (2020) yang menyatakan bahwa orang tua sangat berperan penting ketika anak melaksanakan proses pembelajaran selama study from home ini karena sesungguhnya orang tua adalah madrasah pertama untuk anak-anaknya sebelum anak-anaknya dititipkan kepada sekolah untuk menuntut ilmu. Belajar dari rumah juga dapat meningkatkan kedekatan orang tua dan anak, sehingga orang tua bisa mengetahui kemampuan belajar anaknya selama ini.

Hasil penelitian ini juga dapat di perkuat dengan penelitian yang dilakukan oleh Efendi (2020) dimana hasil penelitiannya menyatakan bahwa keberadaan orang tua adalah tolak ukur keberhasilan pendidikan saat proses pembelajaran jarak jauh berlangsung. Di antara orang tua dan guru harus memiliki kerja sama yang baik (Tambak, 2019) yang dapat dilakukan melalui grup whatsapp untuk menyamai visi dan misi para orang tua dan guru dalam mendidik anak.

\section{Melakukan Home Visit}

Menurut Amry and Badriah (2018) bahwa faktor yang mempengaruhi keaktifan belajar peserta didik salah satunya yaitu, faktor eksternal peserta didik, merupakan faktor dari luar peserta didik seperti: kondisi lingkungan di sekitar peserta didik, lingkungan keluarga, sosial atau bahkan lingkungan sekolahnya sendiri. Dalam proses pembelajaran jarak jauh peserta didik dituntut untuk belajar di rumah, sehingga yang lebih berperan adalah orang tua atau lingkungan keluarga. Peran lingkungan keluarga di dalam proses pembelajaran jarak jauh ini sangat mempengaruhi keberhasilan belajar anaknya, karena proses pembelajaran jarak jauh ini dilaksanakan di rumah.

Fakta di lapangan yang terjadi di masa pandemi seperti sekarang ini ketika peserta didik dituntut untuk melakukan proses pembelajaran di rumah, namun para guru tidak mengetahui bagaimana latar belakang keluarga dan lingkungan setiap masing-masing peserta didik. Sehingga ada saja problem dari beberapa peserta didik saat mengikuti proses pembelajaran jarak jauh, oleh karena itu guru PAI berinisiatif untuk mengadakan home visit atau kunjungan rumah untuk menyelesaikan problematika yang dirasakan para peserta didik dan orang tua saat pelaksanaan pembelajaran jarak jauh berlangsung. Oleh karena itu home visit adalah salah satu upaya guru pendidikan agama Islam dalam mengembangkan keaktifan peserta didik pada pembelajaran jarak jauh, sebagaimana dikemukakan oleh guru PAI sebagai berikut:

"Home visit bertujuan untuk mengetahui mengapa siswa tidak aktif dalam pembelajaran, tidak pernah merespon di grup, tidak pernah bertanya dan tidak pernah mengerjakan tugas, sehingga di adakannya home visit kita bisa menanyakan langsung kepada siswa dan orang tuanya dan kita pun bisa melihat langsung kegiatan yang dia lakukan sebenarnya dirumah, kenapa dia tidak membalas chat guru, tidak merespon di grup dan tidak mengerjakan tugas."

Dari pemaparan yang disampaikan oleh guru PAI di atas dapat dikemukakan bahwa, home visit dilakukan ketika 
terdapat peserta didik yang mengalami permasalahan belajarnya yaitu kurang aktifnya peserta didik saat pelaksanaan pembelajaran jarak jauh. Di bawah ini adalah dokumentasi saat guru PAI melaksanakan home visit kepada peserta didik yang memiliki problematika dalam belajarnya.

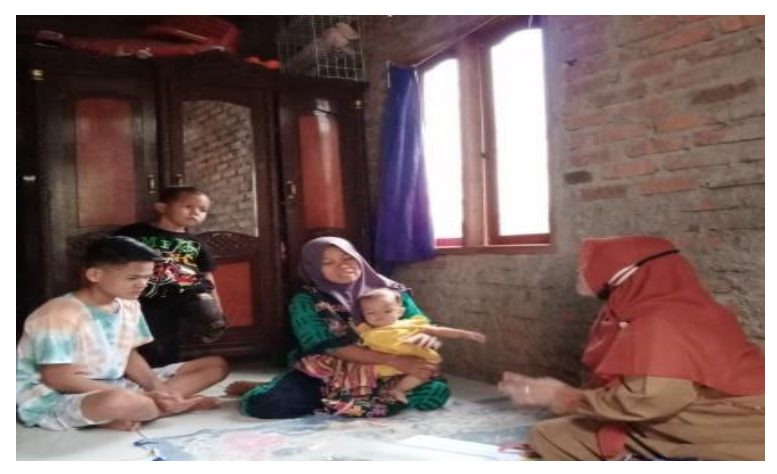

Gambar 4. Pelaksanaan home visit

Hasil penelitian ini sesuai dengan penelitian Nirmala and Annuar (2020) mengakatakan bahwa pelaksanaan belajar dari rumah masih sulit dilaksanakan dengan menggunakan pembelajaran Jarak jauh. Salah satu yang harus disiapkan strategi bagi guru yaitu home visit untuk membentuk kelompok belajar. Temuan penelitian ini juga dapat diperkuat dengan penelitian Mokodompit (2020) yang mengatakan bahwa kegitan home visit dapat mengumpulkan data bagaimana kondisi belajar peserta didik di lingkungannya, dan strategi pelaksanaan home visit sebagai salah satu solusi dalam mengatasi kesulitan belajar peserta didik dalam proses pembelajaran jarak jauh dan merupakan tindakan pencegahan dalam mengurangi miskomunikasi antara guru dan peserta didik.

Oleh karena itu diadakannya home visit agar guru bisa menanyakan langsung kepada peserta didik dan orang tuanya, sehingga guru pun bisa melihat langsung kegiatan yang lakukan peserta didik dan orang tua di rumah dan guru pun dapat mengetahui apa faktor peserta didik tidak aktif dalam mengikuti pembelajaran. Maka dari itu upaya guru melaksanakan home visit ini untuk memberikan solusi kepada orang tua agar bisa mengaktifkan dan memotivasi kembali anaknya untuk semangat belajar walaupun sedang melaksanakan pemebelajaran jarak jauh di masa pandemi.

\section{PENUTUP}

Berdasarkan dari hasil uraian sebelumnya maka dapat dikemukakan temuan penelitian terkait upaya guru pendidikan agama Islam dalam mengembangkan keaktifan peserta didik pada pembelajaran jarak jauh yaitu; pertama, membuat group whatsapp, dengan adanya group whatsapp dapat mempermudah peserta didik dan guru dalam berkomunikasi dan melaksanakan proses pembelajaran jarak jauh; kedua, memotivasi peserta didik, dengan memotivasi peserta didik seorang guru akan mudah mempengaruhi semangat dan minat belajar peserta didik agar tidak mengalami kejenuhan belajar selama pembelajaran jarak jauh berlangsung; ketiga, mengadakan pertemuan tatap muka setiap pekan, pertemuan ini bertujuan agar guru bisa menjelaskan kembali materi yang telah disampaikan melalui whatsapp group agar peserta didik lebih paham jika dijelaskan secara langsung melalui tatap muka, sehingga peserta didik mempunyai rasa tanggung jawab dalam belajarnya. Karena saat pembelajaran jarak jauh berlangsung peserta didik ada rasa tidak takut, dan peserta didik pun sering tidak mengerjakan tugasnya; keempat, mengadakan pertemuan dengan orang tua wali murid, pertemuan ini bertujuan untuk mengetahui apa saja kendala yang dialami para orang tua di rumah saat peserta didik diharuskan belajar dirumah, sehingga pihak sekolah terutama guru bisa mencari solusi atas permasalahan yang dialami para orang tua dirumah; dan kelima, melakukan home visit, upaya guru melaksanakan home visit ini untuk memberikan solusi kepada orang tua agar bisa mengaktifkan dan memotivasi kembali anaknya yang mengalami 
kesulitan belajar atau memiliki masalah dalam melaksanakan proses pembelajaran jarak jauh agar peserta didik aktif kembali dan minat belajarnya pun meningkat. Maka dapat disimpulkan bahwa terdapat lima upaya yang dilakukan guru pendidikan agama Islam di MTs Darul Ihsan dan MTs Mathlaul Anwar dapat mengembangkan keaktifan peserta didik pada pembelajaran jarak jauh. Temuan penelitian ini berimplikasi pada teori upaya guru dalam mengembangkan keaktifan belajar peserta didik di masa pandemi dan diharapkan para guru pendidikan agama Islam bisa lebih meningkatkan strategi mengajarnya di masa yang akan datang.

\section{DAFTAR RUJUKAN}

Abidin, Zainal, et al. "Efektivitas Pembelajaran Jarak Jauh Pada Masa Pandemi Covid-19." Research and Development Journal of Education 1.1 (2020):131.

Ahmad, M. Yusuf, and Syahraini Tambak. "Hubungan Metode Tanya Jawab dengan Minat Belajar Peserta Didik pada Mata Pelajaran Pendidikan Agama Islam." Jurnal Pendidikan Agama Islam Al-Thariqah 2.1 (2017): 89-110.

Ahmad, Muhammad Yusuf, Syahraini Tambak, and Mira Syafitri. "Etika Pergaulan Islami Santri Madrasah Aliyah (MA) di Pesantren Jabal Nur Kecamatan Kandis Kabupaten Siak." Al-Hikmah: Jurnal Agama dan Ilmu Pengetahuan 13.2 (2016): 206226.

Ahmad, Muhammad Yusuf, and Syahraini Tambak. "Penanaman Nilai-Nilai Pendidikan Akidah Melalui Mata Pelajaran Sejarah Kebudayaan Islam (SKI)." Al-Hikmah: Jurnal Agama dan Ilmu Pengetahuan 15.1 (2018): 24-41.

Al Halik, and Zamratul Aini. "Analisis Keaktifan Siswa Dalam Proses Pembelajaran Daring Di Masa Pandemi COVID-19." ENLIGHTEN Uurnal Bimbingan Dan Konseling Islam) 3.2 (2020):131-41.
Amry, Zainul, and Laelatul Badriah. "Pembelajaran Tematik Sebagai Upaya Meningkatkan Keaktifan Peserta Didik." Elementary: Islamic Teacher Journal 6.2 (2018):254-70.

Arianti. "Peranan Guru Dalam Meningkatkan Motivasi Belajar Siswa." Didaktika: Jurnal Kependidikan 12 (2018):117-34.

Cahyati, Nika, and Rita Kusumah. "Peran Orang Tua Dalam Menerapkan Pembelajaran Di Rumah Saat Pandemi Covid 19." Jurnal Golden Age 4.1 (2020):152-59.

Darajat, Rafi, et al. Upaya guru pendidikan agama Islam ( PAI) dan budi pekerti dalam meningkatkan prestasi akademik peserta didik pada mata pelajaran PAI dan budi pekerti dosen Prodi Pendidikan Agama Islam ( PAI) STAI Al Hidayah Bogor, 2019.

Dharma, ketut Budi; Filosaria kristin. "Efektivitas Pembelajaran Jarak Jauh Dengan Menggunakan Aplikasi Zoom Dan Google Classroom Terhadap Keaktifan Belajar Ips Siswa Kelas 5 Sd." Jurnal Pendidikan Rokania 6.1 (2021).

Efendi, Didik. "Peran Orang Tua Dalam Pembelajaran Model Distance Learning Di Sekolah Dasar Kota Jayapura." Al-Madrasah: Jurnal Pendidikan Madrasah Ibtidaiyah 5.1 (2020):54.

Graham, Sandra. "An attributional theory of motivation." Contemporary Educational Psychology 61 (2020): 101861.

Haibah, Mujahidatul, et al. "Pembiasaan Membentuk Karaktek Peserta Didik Madrasah Miftahul Huda Musi Rawas Utara." Jurnal Pendidikan Agama Islam Al-Thariqah 5.2 (2020):23-32.

Hambali, Muh. "Manajemen Pengembangan Kompetensi Guru PAI." Jurnal MPI (2016).

Hamzah, Desi Sukenti, Syahraini Tambak, and Wisudatul Ummi Tanjung. "Overcoming self-confidence of Islamic religious education students: The influence of personal learning 
model." Journal of Education and Learning (EduLearn) 14.4 (2020): 582-589.

Hamzah, Hamzah, Syahraini Tambak, and Nella Ariyani. "Upaya Guru Pendidikan Agama Islam dalam Pembentukan Kepribadian Islam Siswa di SMA Negeri 2 Kelayang Kabupaten Indragiri Hulu." AlHikmah: Jurnal Agama dan Ilmu Pengetahuan 14.1 (2017): 76-95.

Hapsari, Fadjriah, et al. "Peran Guru Dalam Memotivasi Belajar Siswa Selama Kegiatan Pembelajaran Jarak Jauh." Research and Development Journal of Education 7.1 (2021):193

Hardani. Metode Penelitian Kualitatif \& Kuantitatif. Yogyakarta: Penerbit Pustaka Ilmu, 2020.

Hartini, Siregar Evelin;Nara. Teori Belajar Dan Pembelajaran. Bogor: Ghalia Indonesia, 2017.

Hotmian. "Meningkatkan Keaktifan Dan Hasil Belajar Pendidikan Agama Kristen Siswa Dengan Menerapkan Strategi Sort Card Pada Siswa Kelas IX SMP Negeri 1 Gerbang Tahun 2017-2018." Jurnal Pendidikan Tabularasa 15.3 (2018):283-93.

Jeong, Jin $\mathrm{Su}$, et al. "Effects of Active Learning Methodologies on the Students' Emotions, Self-Efficacy Beliefs and Learning Outcomes in a Science Distance Learning Course." Journal of Technology and Science Education 9.2 (2019):217-27

Kudryashova, Alexandra, et al. "Teacher's Roles to Facilitate Active Learning." Mediterranean Journal of Social Sciences (2015).

Kurniasari, Asrilia, et al. "Analisis Efektivitas Pelaksanaan Belajar Dari Rumah (Bdr) Selama Pandemi Covid19." Jurnal Review Pendidikan Dasar: Jurnal Kajian Pendidikan Dan Hasil Penelitian 6.3 (2020):1-8.

Kusuma, Jaka Wijaya, and Hamidah Hamidah. "Perbandingan Hasil Belajar Matematika Dengan Penggunaan Platform Whatsapp
Group Dan Webinar Zoom Dalam Pembelajaran Jarak Jauh Pada Masa Pandemik Covid 19." JIPMat 5.1 (2020).

Lestari, Iis Dewi. "Peranan Guru Dalam Penggunaan Media Pembelajaran Berbasis Information And Communication Technology (ICT) Di SDN RRI Cisalak." SAP (Susunan Artikel Pendidikan) 3.2 (2018):13742

Mansir, Firman, and Halim Purnomo. “Optimalisasi Peran Guru PAI Ideal Dalam Pembelajaran Fiqh Di Masa Pandemi Covid-19." Jurnal Pendidikan Agama Islam Al-Thariqah 5.2 (2020):97-105

Manurung, Rikson Parsaoran. "Jurnal Penelitian, Pendidikan Dan Pemanfaatan Media Whatsapp Sebagai Media Literasi Digital Siswa Pada Pembelajran Jarak Jauh Di SMA Swasta Santo Thomas 2 Medan." Jurnal Penelitian, Pendidikan Dan Pengajaran 1.3 (2020):239-44.

Mokodompit, Intan Safitri. Home Visit Sebagai Refleksi Kurikulum Darurat Covid-19: Kesiapan Guru, Respon Siswa, Materi Dan Hasil Belajar Di Madrasah Tsanawiyah Pendahuluan Peraturan Menteri Agama Republik Indonesia Nomor 60 Tahun 2015 Tentang Penyelenggaraan Pendidikan Madrasah 2 (2020):119-31.

Muhyani. Metodologi Penelitian Cara Mudah Melakukan Penelitian. Bogor:Uika Press, 2019.

Naziaha, Syifa Tiara, et al. "Analisis Keaktifan Belajar Siswa Selama Pembelajaran Daring Pada Masa Covid-19 Di Sekolah Dasar." Jurnal JPSD 7.2 (2020):109-20.

Niemi, Hannele, et al. "Active Learning Promoting Student Teachers' Professional Competences in Finland and Turkey." European Journal of Teacher Education 39.4 (2016):47190.

Nirmala, Besse, and Haerul Annuar. "Home Visit: Strategi PAUD Dari 
Rumah Bagi Guru Di Daerah 3T Pada Masa Pandemi Covid-19." Jurnal Obsesi : Jurnal Pendidikan Anak Usia Dini 5.2 (2020):1052-62.

Nugraha, Aman Kusna. "Peningkatan Kektifan Dan Prestasi Belajar IPA Materi Sistem Organisasi Kehidupan Makhluk Hidup Dengan Media Flash Card Matching Game Pada Peserta Didik Kelas VII F SMP Negri 1 Pejagoan Semester 2 Tahun Pelajaran 2018/2019." Konfergensi Indonesia Scientific Knowledge Center 5 (2019).

Pratama, Hendrik, and Andista Candra Yusro. "Implementasi Whatsapp Mobile Learning Untuk Meningkatkan Hasil Belajar Mahasiswa Pokok Bahasan Pengenalan Komponen Elektronika." Jurnal Pendidikan Fisika Dan Keilmuan (JPFK) 2.2 (2016):65.

Prawiyogi, Anggy Giri, et al. "Efektifitas Pembelajaran Jarak Jauh Terhadap Pembelajaran Siswa Di SDIT Cendekia Purwakarta." Jurnal Pendidikan Dasar 11.1 (2020):94101.

R Dahlan, M. Konsep Pembelajaran Aqidah Akhlak. Yogyakarta:Deepublish, 2016.

Ramayulis. Profesi Dan Etika Keguruan. Jakarta:Kalam Mulia, 2016.

Rina Purnami. "Upaya Meningkatkan Keaktifan Siswa Kelas IX D MTsN 1 Hulu Sungai Utara Dimasa Pandemi Covid 19 Melalui Bimbingan Klasikal Secara Online." Jurnal Pendidikan Hayati 6.3 (2020).

Rosenberg, Hananel, and Christa SC Asterhan. "'WhatsApp, Teacher?"Student Perspectives on TeacherStudent WhatsApp Interactions in Secondary Schools." Journal of Information Technology Education: Research 17 (2018): 205-226.

Rusman. Belajar Dan Pembelajaran Berorientasi Standar Proses Pendidikan. Jakarta:Kencana, 2017.

Ryan, Richard M., and Edward L. Deci. "Intrinsic and extrinsic motivation from a self-determination theory perspective: Definitions, theory, practices, and future directions." Contemporary

Educational Psychology 61 (2020): 101860.

Sabaniah, Siti, et al. "Peran Guru Dalam Pelaksanaan Pembelajaran Jarak Jauh Di Tengah Wabah Covid - 19." Edunesia: Jurnal Ilmiah Pendidikan 2.1 (2021): 43-54.

Sadikin, Ali, and Afreni Hamidah. "Pembelajaran Daring Di Tengah Wabah Covid-19:(Online Learning in the Middle of the Covid-19 Pandemic)." Biodik 6.2 (2020):21424.

Setyaningsih, Kurnia Dwi. "Analisis Pelaksanaan Pembelajaran Jarak Jauh Di Sd Negeri Karangrena 03." Jurnal Riset Pendidikan Dasar (JRPD) 1.2(2020): 19-27.

Siregar, Irma Suryani. "Konstruksi Manajemen Kurikulum Di Perguruan Tinggi Agama Islam." Jurnal Pendidikan Agama Islam Al-Thariqah 5.2 (2020):43-55

Suarni. "Melalui Pendekatan Pembelajaran Pakem Untuk Kelas Iv Sd Negeri 064988 Medan Johor." Journal of Physics and Science Learning 1.2 (2017):129-40.

Sukenti, Desi, and Syahraini Tambak. "Developing Indonesian Language Learning Assessments: Strengthening the Personal Competence and Islamic Psychosocial Teachers." International Journal of Evaluation and Research in Education 9.4 (2020): 1079-1087.

Sukenti, Desi, and Syahraini Tambak. "Strengthening Islamic Psychosocial and Self-confidence in Develophing Student Thinking Creative." ICOSEEH 20194 (2019): 446-453.

Tambak, Syahraini, and Desi Sukenti. "Strengthening Islamic Behavior and Islamic Psychosocial in Developing Professional Madrasah Teachers." Cakrawala Pendidikan: Jurnal Ilmiah Pendidikan 39.1 (2020): 145-176.

Tambak, Syahraini. "Pendidikan Etika Bergaul Islami Dalam Keluarga "Nilai 
Pendidikan Etika Berlaku Adil Orangtua dengan Anak dalam Pergaulan Keluarga Perspektif Hadits"." Jurnal Pendidikan Agama Islam Al-Thariqah 4.1 (2019): 1-20.

Tambak, Syahraini, M. Yusuf Ahmad, and Desi Sukenti. "Strengthening Emotional Intelligence in Developing the Madrasah Teachers' Professionalism (Penguatan Kecerdasan Emosional dalam Mengembangkan Profesionalisme Guru Madrasah)." Akademika 90.2 (2020).

Tambak, Syahraini, Mawardi Ahmad, Desi Sukenti, and Abd. Rahman bin Abd. Ghani. "Profesionalisme Guru Madrasah: Internalisasi Nilai Islam dalam Mengembangkan Akhlak Aktual Siswa." Jurnal Pendidikan Agama Islam Al-Thariqah 5.2 (2020): 79-96.

Tambak, Syahraini, Amril M., Zuriatul Khairi, and Desi Sukenti. "Development of Madrasah Teacher Professionalism by Strengthening the Khalifah Concept and Islamic Psychosocial

Perspective." International

Conference on Islamic Education (ICIE 2018). Atlantis Press, 2018.

Tambak, Syahraini, Amril Amril, and Desi Sukenti. "Islamic Teacher Development: Constructing Islamic Professional Teachers Based on The Khalifah Concept." Nazhruna: Jurnal Pendidikan Islam 4.1 (2021): 117135.
Wahyuni, Ida Windi, and Ary Antony Putra. "Kontribusi Peran Orangtua Dan Guru Dalam Pembentukan Karakter Islami Anak Usia Dini." Jurnal Pendidikan Agama Islam AlThariqah 5.1 (2020): 30-37.

Yulianingsih, Wiwin, et al. "Keterlibatan Orangtua Dalam Pendampingan Belajar Anak Selama Masa Pandemi Covid-19." Jurnal Obsesi : Jurnal Pendidikan Anak Usia Dini 5.2 (2020): 1138-50.

Zahara, Zahara, and Ibnu Sina. "Peran Media Teknologi Pendidikan Pada Kegiatan Belajar Mengajar Di Tengah Pandemik Covid-19." Rausyan Fikr: Jurnal Pemikiran Dan Pencerahan 17.2 (2020).

Zaman, Badrus. "Penerapan Active Learning Dalam Pembelajaran Pai." Jurnal As-Salam 4.1 (2020):13-27.

Zein, Muh. "Peran Guru Dalam Pengembangan Pembelajaran." Jurnal Inspiratif Pendidikan 5.2 (2016):27485.

Zulkanain, Nani Amalina, Suraya Miskon, and Norris Syed Abdullah. "An adapted pedagogical framework in utilizing WhatsApp for learning purpose." Education and Information Technologies 25.4 (2020): 2811-2822. 